\title{
The Role of Algorithms in the Crisis of Democracy
}

\author{
By Gloria Marchetti* \\ The essay aims at analyzing the relationship between algorithms and democracy. \\ Algorithms used by platforms can lead to disinformation so as to produce an \\ impact on democracy. The essay then focuses on the possible solutions to deal \\ with this phenomenon and assesses their limits.
}

Keywords: Algorithms and democracy, political disinformation, fake news, democratic electoral process, policy decision process.

\section{Introduction}

Algorithms play a fundamental role in current information. In the past, traditional media managed the production, verification and communication of news. In online information, instead, it is algorithms used by the platforms that are relevant. Algorithms are able to sort the information that appears on the users' screen. This order of news, however, is not the result of an objective and neutral search: instead, algorithms select the information to be proposed to individual users based on their interests, opinions and prejudices. This selection is possible because the platforms collect the users' personal data, used while surfing the Net and, through their analysis and aggregation, are able to predict the users' future behavior (Pasquale 2015).

These elements could endanger some democratic principles and values. Firstly, democracy could be endangered precisely by the weakening of the information role that traditional mass media had in the past: in fact, they would no longer be able to select and control information or to deny false news (Levi 2018, Baker 1998). This is also because citizens tend to get more and more informed through the Net and less and less through traditional media. Indeed, many citizens, especially younger ones, inquire only through the Net.

Secondly, the users, through profiling operated by algorithms, are at risk of receiving only that news that reflects their orientations, opinions and prejudices. On the other hand, users also tend to search online for information that reflects their way of thinking and share it with other users. Furthermore, algorithms, in addition to selecting the news to be proposed to each user, would also produce another effect, object of study in recent years: the users tend to close and isolate themselves in the so called 'filter bubble' that filters the reality of the facts, prevents the comparison with different points of view and creates an echo effect (Pariser 2011). This can create another phenomenon defined as 'confirmation bias', which is the strengthening of one's own opinions and prejudices. In this way, the principle of information pluralism could be severely penalized.

\footnotetext{
${ }^{*}$ Researcher/Assistant Professor of Constitutional Law, University of Milan, Italy.
} 
Thirdly, algorithms not only contribute to creating and spreading fake news, but are also able to influence users, who tend to believe it, because it is truthful, but above all because it is in line with their ideas. Moreover, the average user tends not to verify the truthfulness of the news but believes it also due to a growing mistrust towards traditional mass media and because of the number of shares and 'likes'. Furthermore, platforms tend to keep the user as much as possible on certain pages, through the dissemination of news, even false news, capable of arousing curiosity and emotions.

Thus, algorithms can play a fundamental role in creating and disseminating ad hoc fake news, for particular purposes. The purposes can be: limit the right to be correctly informed; orienting public opinion; discredit politicians and governments and their actions and, consequently, condition the voters' vote. This fake news, artfully created for specific purposes, is potentially capable of producing serious effects. On one hand, the closure of the users in a 'filter bubble' and the 'echo effect' contribute to amplify false news especially among like-minded people. On the other hand, the phenomenon of 'confirmation bias', leads users to believe not so much in the true news but in that which confirms their opinions and their prejudices. Consequently, these users will tend to share information especially with those who are 'locked up' in the same 'bubble'. In this way, fake news can be used as a tool for ideological, cultural and political propaganda. This could strongly condition public and political opinion and user behavior. There could be a real 'manipulation' of information, conceived artfully, by ideological movements, power groups or politicians.

In the media context described above, therefore, the risk is a penalization of some democratic principles: the principle of pluralism of information; the principle of freedom of information like the basis for the formation of a public opinion that leads to a conscious exercise of civil and political rights.

Furthermore, there is another risk, more particularly, for representative democracy. Algorithms are increasingly present in policy decision-making processes but this should not replace democratic systems based on indirect democracy.

There are also other problems. Many users do not know that the information they receive online is selected on the basis of their profiles but believe that it is neutral. In any case, users who receive selected information, based on a profiling that could influence their behavior, ignore the methods and operating criteria used by algorithms, since these are unknown. This poses problems of transparency and neutrality in the Net which could jeopardize the exercise of freedom of expression on the Internet. In addition, users are often unable to distinguish between false and true information (Barthel et al. 2016, Donald 2016).

The purpose of this study is to offer a contribution to the ongoing scientific debate on the impact of algorithms on democracy. In particular, believing that there is a danger for democracy that would justify regulatory intervention by States, some proposals for measures that can be taken to deal with this phenomenon will be put forward.

This paper begins with an introduction to the issues linked to the relationship between profiling online users, through the algorithms, the fake news created 
specifically to manipulate public opinion and the dangers for democracy. Next, a literature review will show how the recent doctrine has focused on these issues and many authors have highlighted the risks to democracy due to the spread of fake news. In accordance with this doctrine, it will be argued that platforms that use algorithms are potentially capable of producing negative consequences on pluralist and representative democracy. On one hand, we will examine the role of algorithms in changes in political information - changes characterized by the spread of fake news and the strengthening of personalization of politics, polarization radicalization of the political debate - and on the impact on the democratic electoral processes. On the other hand, the role of algorithms in the policy decision process will be analyzed and the risks for representative democracy will be assessed. The framework that will be described in the work, will lead to a belief that a regulatory intervention is necessary to limit the creation and dissemination of that news, specifically created for the purpose of influencing users' choices and behaviors, as well as their vote, with serious consequences for the democratic systems. On the other hand, the hypothesis of regulatory interventions, that limit the use of platforms that involve users in the policy decision process, will also be evaluated, because the mechanisms of operation of algorithms are obscure and many citizens would be excluded. Then, the possible measures that can be introduced, at the national or European level, aimed at limiting the impact of algorithms on democracy will be examined. Measures aimed at: limiting the creation and dissemination of fake news specifically created to manipulate citizens' votes; making the functioning mechanisms of algorithms more transparent; providing for transparency obligations and tools to identify the author of the false news, through forms of accountability in their dissemination and the possibility of denying them, through debunking tools, rectifying them or, sometimes, removing them, after an evaluation by a judicial authority; enhancing the Media Literacy of network users to develop in them a critical spirit towards the news. Then, the effectiveness of the various proposed measures will be assessed, also on the basis of experiments conducted in some countries and researches conducted, in this regard, especially in the United States. Finally, we will conclude our results arguing that a single measure, provided for by state regulations, would not be able to limit the phenomenon of fake news and to make the algorithms' operating methods more transparent. In conclusion, therefore, taking into account each measure considered has limits, it will be argued that a regulation that provides for a mix of different measures would be appropriate. It should be anticipated, however, that a mix of measures is not expected to solve the problem of the impact of algorithms on democracy.

\section{Literature Review}

Research on the impact of algorithms on democracy has started in the international arena in a relatively recent period. Some of the work in the last years is summarized below. 
The changes in online information have been studied by Salganik et al. (2006), Hodas and Lerman (2012), McNair (2017), Nematzadeh et al. (2017) and Riva (2018).

Shao et al. (2018) conducted research on a sample of articles, showing that a great deal of online news is untruthful.

Reaney (2013), Barthel et al. (2016) and Donald (2016) highlighted the difficulties for users in the social media environment, to distinguish between true and false news.

Baron and Crootof (2017) have shown, through a series of researches, that users tend to believe more in false news on the Net than in real news spread by traditional mass media, because they no longer trust them.

On the relationship between online information (or rather disinformation), the formation of public opinion and democracy, research has been conducted by Morozov (2011), Panarari (2017), Papa (2018), Cuniberti (2017), Caravita (2018), Manetti (2018), Pitruzzella (2017), Costa (2016), Borello (2017), Pinelli (2017), West (2017), Syed (2017), Balkin (2018), Boccia Artieri and Marinelli (2018), Gurumurthy and Bharthur (2018), Mezza (2018), Smith-Roberts (2018).

Pasquale (2015) talks about the Black Box Society by assimilating the platforms to a black box: in the same way as black boxes the platforms collect our data but it is not possible to know how they work.

Baker (1998) and Levi (2018) wonder if the weakening of the informative role of the press and, more generally, of the traditional mass media does not constitute a danger for democracy, as they are no longer able to neutralize false news and exercise their role as "gatekeepers" on the activities of the institutions and power.

Pariser (2011) highlights the risk that the user tends, in the network, to close himself in a 'bubble' built on the basis of his ideas, beliefs and prejudices, reinforcing them. Other studies on the topic have been conducted by Zuiderveen Borgesius et al. (2016) and Pitruzzella (2017).

Aalberg and Curran (2012), Donati (2017), Pizzetti (2017), Tucker et al. (2017), Bassini and Vigevani (2017) and Gallone (2019) have studied the possible effects of fake news on democracy.

More specifically, D'Atena (2018) and Ciarlo (2018) believe that fake news can influence and manipulate the consent of the voters and, consequently, their vote. Frosini (2017) has a different opinion. Huighe (2016), Berghel (2017), Bennett and Livingston (2018), Lorusso (2018), Morgan (2018), Ziccardi (2019), Allcott and Gentzkow (2017), Groshek and Koc-Michalska (2017) and Caravita (2019) also studied the topic.

Frankovic (2016), Gaughan (2017), Russonello (2016), Persily (2017), Faris et al. (2017) and Ciarlo (2018) highlighted the impact of the Net on the American presidential election vote and Brexit.

The studies of Keyes (2004), Sinclair and Wars (2006), Ratkiewicz et al. (2011), Bakshy et al. (2015), Rožukalne (2015), Huighe (2016), Silverman (2016), Quattrociocchi and Vicini (2016), Quattrociocchi and Vicini (2018), Giglietto et al. (2019), Iacoboni (2016), Gili and Maddalena (2017), Spohr (2017), Grassegger and Krogerus (2017), Bistagnino and Fumagalli (2018), Del Vicario et al. (2019), 
Perucchietti (2018), Visco Comandini (2018) and Reinemann et al. (2017) have highlighted the changes in online political information.

Furthermore, recent studies have dealt, more specifically, with the tools to combat the phenomenon of fake news, also highlighting their limits. Some studies listed below are significant in this context.

Butler (2018) expects a legislative intervention to deal with the phenomenon of fake news. On the contrary are Goldberg (2018), Klein and Wueller (2017).

The studies of Nyhan and Reifler (2010), De Keersmaecjer and Roets (2017) and Nyhan and Reifler (2019) have highlighted the limits of the correction or removal systems of fake news.

De Keersmaecjer and Roets (2017), Royster (2017) and Jolls and Johnsen (2018) believe that Media Literacy is ineffective.

Nyhan and Reifler (2010), Nyhan (2017) and Pennycook and Rand (2017) believe that fact checking and warning systems are ineffective.

The studies of Zollo et al. (2017) and Baron and Crootof (2017) showed that debunking is ineffective.

\section{Methodology in the Analysis of Topics Covered and Expected Results}

The methodology used in the research of problems and concepts includes a careful analysis of updated literature, capable of expressing the theoretical and scientific, as well as practical, findings of the topics covered in this study.

Considering the context in which the theme of the relationship between algorithms and democracy is developing, without a practical approach, many of the considerations made would not be understandable. For this reason, the results of researches carried out in recent years have been examined, which concern the analysis of the facts and practical implications related to the impact of algorithms on democratic processes. On the basis of this researches, also based on the empirical experiences that have taken place, in the United States and in European countries, it will be possible to argue that platforms that use algorithms are potentially able to produce negative consequences on pluralist and representative democracy.

The methodological approach is the legal one and the solution proposed to deal with this phenomenon is based on regulatory intervention.

The method used in the research is aimed at motivating the proposal to introduce legislation, at the level of individual States, or at the level of the European Union, which provides for adequate measures aimed at limiting fake news harmful to democracy and at enhancing the transparency of algorithms. However, the results of researches carried out in recent years, also on the basis of the examination of experiments introduced in some countries and by the European Union, have revealed the limits of these measures.

Therefore, the expected result of the research is not to identify the best solution to deal with the problems covered by the study but, rather, to demonstrate the need for a regulatory intervention that provides for a mix of measures. 
Measures that, even if they cannot completely solve the problem of the impact of algorithms on democracy, can, at least in part, limit its negative effects.

\section{The Role of Algorithms in Changing Political Information and its Consequences on the Democratic Electoral Processes}

The algorithms used by the platforms have changed the characteristics of political information with possible consequences for democracy.

Among the fake news that algorithms help to create and disseminate there are those concerning politics, in general, and election campaigns, in particular. Thanks to 'profiling' it is possible to know the users' orientations and prejudices. Leveraging on profiling, politicians tend to give more prominence to news that can give them greater visibility and to arouse empathy and emotions in users (Ratkiewicz et al. 2011, Silverman 2016, Shao et al. 2018). The objective of the political information, in this case, is no longer to inform about the activity of politicians or parties, but to obtain consensus and discredit opponents and their actions, through the creation of fake news and ad hoc reality (Keyes 2004, Gili and Maddalena 2017, Grassegger and Krogerus 2017, Pitruzzella et al. 2017, Bistagnino and Fumagalli 2018). So, platforms that use algorithms play an important role in electoral and democratic processes. Because user profiling can be used, political opinions are easily orientable by this fake news. This has important consequences not only for the right to information but also for the results of the elections, thus affecting democracy itself. In fact, starting from the vote on Brexit and for the American elections, the problem of the manipulation of consensus and the 'pollution' of the electoral campaigns, also by foreign governments, has arisen during several elections: for example, for the presidential elections in France in 2017, for the political elections in Italy in 2018 and for the European elections in 2019. And it is precisely since 2016, following the election of President Trump that the attention of scholars has focused on the risk that information on the Net, through the 'profiling' of users - operated by algorithms used by search engines and by social media - can be used as a tool for political propaganda. Through profiling, in fact, the platforms have the possibility of orienting public opinion, limiting the comparison with a plurality of positions and information and may be able to manipulate the voters and, consequently, their vote (Persily 2017, Cuniberti 2017, Caravita 2018, Manetti 2018, Papa 2018, Berghel 2017, Bennett and Livingston 2018, Ciarlo 2018, D'Atena 2018, Morgan 2018, Ziccardi 2019, Allcott and Gentzkow 2017, Groshek and Koc-Michalska 2017). It is true that it is not possible to evaluate, in concrete terms, the impact of electoral propaganda on voters' voting through platforms, and, in particular, through social media. However, it seems undeniable that the media environment, dominated by algorithms, favors the manipulation of consensus and electoral campaigns.

Equally dangerous for democracy is the personalization of policy where the relationship between politician and voter profiled becomes direct. In this context, it is not relevant information on the activities of political parties or the government but the message of the politician, in order to obtain consensus (Perucchietti 2018). 
On the other hand, the Web network is often perceived by users as a means of expressing dissent and to destabilize traditional politics, traditional media and intermediate bodies, including political parties. From this point of view, disintermediation is a problem in the countries based on representative democracy.

Furthermore, a danger to democracy is represented by the 'pollution' of the online public debate. The language of online political information is different from that used by traditional media (Mazzoleni 2012). Because the message tends to be direct and shared, the language is often characterized by exaggerated and aggressive tones that seem to leave little space for dialogue and political confrontation. In this context, the fake news strengthens polarization due to the 'filter bubbles' and 'echo chambers' created by users' tendencies to follow those who share their opinion and prejudices. In this way, a party polarization is created in a 'post-truth' society: the political debate is no longer rational because users tend to isolate themselves in a 'bubble' and remain closed to different positions. The polarization of some topics occurs above all before election time: fake news online tends to amplify and polarize some topics, like populism, nationalism, white supremacy, anti-immigrant sentiment, homophobia, antimulticulturalism, antisemitism and racism and the need for strong leadership to restore a social order (Ciarlo 2018).

In this media context, the most radical parties seem to be gaining ground because - thanks to profiling through algorithms - they leverage the opinions and prejudices of the voters. The candidates tend to create sensational information in order to discredit the opponents (Rožukalne 2015, Huighe 2016). Trump's campaign was a demonstration of this. The Net tends to produce and disseminate fake news which, however, is believed to be true by users who are often induced to support radical political movements, especially right-wing ones. These radical right-wing movements tend to reject the institutions, traditional parties and traditional media. It is true that the polarization and radicalization of politics are due, more generally, to a series of contingent circumstances, such as: the crisis of traditional parties, the inability of the political class to make viable proposals in the long run and to cope with certain economic and social situations. Circumstances that have increased citizens' distrust of traditional parties, institutions and the press, as well as systems of representative democracy. But it is equally true that the Net favors and amplifies the polarization and radicalization of politics. It is precisely citizens who seek alternative information and new political movements. Of course, there are also some radical leftist movements that spread fake news. Similar to the right-wing movements, there are radical left movements that tend to discredit traditional parties and democratic institutions. This could help increase the legitimacy crisis of democracy (Della Porta et al. 2017). In this context, one could point at, for example, the anti-political mobilization such as Occupy Wall Street and the Spanish M-15 Indignados and movement-parties such as Podemos in Spain. Even in cases where political information does not fit into a radical framework, there has been a polarization and radicalization of the political debate that have led to institutional divisions within democracies. Significant, in this sense, are the examples regarding the Brexit vote in the United Kingdom, the rise 
of the Five Star movement in Italy and the victory of Emmanuel Macron in France (Iacoboni 2016).

These phenomena develop for several reasons. First of all, citizens seem to harbor greater distrust, than in the past, towards traditional politics, parties and the old media. Furthermore, algorithms used by platforms, being able to create and disseminate credible fake news for users, because they are profiled, make them believe that their minority opinion is shared by many.

All this can have serious consequences for democracy such as: a limitation of freedom to receive correct and objective information and damage democratic electoral processes.

\section{The Role of Algorithms in the Policy Decision Process: The Risk for Democracy}

On the other hand, a threat to democracy stems from the role of algorithms in the policy decision process and the consequences for citizen rights.

On the one side, through the platforms that use algorithms, a damage and a delegitimization of the representative democracy, takes place. Through the creation of fake news, by politicians, political parties, foreign governments, power groups or lobbies, not only public opinion and the vote of the voters are conditioned, but also the choices of politicians and government. The politicians, who through social media establish an increasingly direct relationship with the voters, will tend to make choices based on their requests. This could involve the risk that these choices are not prudent and effective in the long run but rather dictated by the need for immediate consent, which can be assessed through sharing and 'likes'. Just as voters can be conditioned by online political propaganda in their vote, politicians can be conditioned in their decisions by the amount of 'likes' received. The problem is that, in this way, voters who do not use the Net may not have the opportunity to make their voices heard.

On the other hand, algorithms should enhance citizens' ability to participate in public life. However, even in this case, many citizens would be excluded from this participation. Such participation has nothing to do with new types of direct, deliberative and participatory democracy, which can be considered positive, but only if they guarantee the involvement of all citizens. Furthermore, algorithms should not replace democratic institutions and the democratic systems based on indirect democracy. It is not acceptable to have completely automated political decisions, but despite that, algorithms are increasingly present in the decisionmaking processes. As a matter of fact, in some countries (e.g., Denmark) many public policies are adopted by algorithms with risks to democracy. Even in Italy the initial success of the Five Stars was partly due to the idea of citizen participation in the choices of politicians through the so-called Rousseau platform. The problem is that the algorithms are controlled by private corporations and elites and that the lack of transparency of some automated data processing could threaten democracy. 


\section{The Need to Introduce Regulation to Limit the Impact of Algorithms on Democracy: Examples of Regulation}

In the light of the considerations made so far, it is believed that there is a danger for democracy such as to justify regulatory intervention, by individual States or the European Union. This in order to limit the impact of algorithms in democratic electoral processes and in the policy-decision processes. This is because the voting of the voters must be unconditional and policy-based tools based on platforms that endanger representative democracy are not admissible.

On the one hand, a regulation aimed at limiting the spread of fake news capable of altering democratic values should be introduced. In this regard, some European countries have adopted laws that provide for measures such as: the criminal repression of fake news; the provision of transparency obligations for Internet Server Providers (ISP) and the correction of fake news; the promotion of Media Literacy Programs. The disciplines introduced in Germany (Gesetz zur Verbesserung der Rechtsdurchsetzung in sozialen Netzwerken - Netzwerkdurchsetzungsgesetz - NetzDG, n. 536/17, 30 June 2017, aimed at countering all false news) and in France (Loi n. 2018-1202 du 22 décembre 2018, aimed at combating online disinformation during election periods) are based on penal repression: the purpose is to remove fake news and to punish criminally those who publish or disseminate it on the Net. Always with the aim of countering fake news, legislation has also been established in the order to impose obligations on ISP, to guarantee greater transparency and identify the authors of false news or to allow the ratification of certain information. The French law of 2018, for example, in addition to what has already been said, imposes on the platform's transparency obligations, in the pre-election periods, when they distribute sponsored contents, and provides for penalties in case of non-compliance. The Spanish law of 2018 (Ley Orgánica 3/2018, de 5 de diciembre, de Protección de Datos Personales y garantía de los derechos digitales) requires platforms to adopt protocols to allow users to exercise the right of rectification against users that disseminate content that violates, among other things, the right to receive truthful information. Other countries, such as Finland and Great Britain, have instead adopted Media Literacy measures for users. These are measures that aim at providing users with useful tools to consider information in a more conscious, independent and critical way, in order to assess its veracity.

On the other hand, legislation aimed at pushing platforms to clarify the functioning mechanisms of their algorithms should be introduced. In this regard, it is appropriate to remember that the Communication of the European Commission of 26 April 2018 (COM (2018) 236 final), entitled 'Tackling online disinformation: a European approach', provided for the elaboration of a Code of good practices, valid in each Member State, on the issue of disinformation, aimed - in addition to enhancing accountability and fact checking measures - to make the mechanisms of operation of algorithms more clear. Subsequently, the self-regulation code for digital platforms, of September 2018, aimed at combating the spread of false or misleading news, aimed at influencing the opinion of citizens or guaranteeing advertising income, was signed by some large digital platforms (Facebook, Google 
and Mozilla), by some associations of platforms (EDIMA - Association of platforms) and advertising. However, among the aspects that have not been adequately considered by the Code, in contradiction with the guidelines indicated in the Commission Communication, there are precisely those concerning: the provision of greater transparency, both in terms of resources and sponsorships, and the platforms' commitment to clarify the functioning mechanisms of algorithms. However, this is an objective that will be difficult to pursue.

\section{Conclusions: The Difficulties in Defining Effective Measures to Limit the Impact of Algorithms on Democracy}

We can therefore argue that there is a need to introduce legislation, at the level of individual States or of the European Union, which provides for adequate measures aimed at limiting fake news harmful to democracy and at enhancing the transparency of algorithms. The problem, which we will try to highlight, is that these measures, however, have limitations, as well as being often difficult to implement.

First of all, in order to limit anonymity, transparency and accountability obligations should be provided for the activity of spreading false news capable of manipulating political opinions and conditioning voters' voting. Accountability tools are particularly useful because often users, politicians, power groups and governments use, in addition to invented names, fake accounts, i.e., anonymous or fake digital profiles, often created by robots. This is not a generalized introduction of the tool of anonymity: in general, in fact, the right to anonymity must be protected online, because it protects the freedom of expression and criticism in repressive or dictatorial regime contexts (think of the role of the Internet in the Arab Spring protesters). Instead, it would seem appropriate to introduce forms of struggle against anonymity in the case of fake news specifically disseminated by political subjects or power groups, in order to manipulate the political opinion of users and condition their vote, with repercussions on democracy. Of course, this is a delicate issue, because a part of the political class and many scholars are opposed, in any case, to the provision of tools that limit the right to anonymity. From a practical point of view, moreover, users, through new and sophisticated IT tools, could manage to circumvent the obstacle of the limit to anonymity.

Tools aimed at faciliting the reporting, by users, of fake news and fact checking tools, in order to verify the objectively false news that causes damage to democracy, could be introduced. Even fact checking tools, however, could prove to be ineffective. It would be impossible to entrust private individuals with a task of monitoring and verifying the news, because the mechanisms of operation of algorithms remain largely obscure both for users and for those who should adopt contrasting solutions. Furthermore, the hypothesis of using algorithms as fact checking tools to automatically identify false news poses some problems. It is doubtful that, at the moment, an algorithm could be able to verify the reliability and truthfulness of the news. But even if there were algorithms capable of completely eliminating certain fake news, dangerous for democracy, it cannot be 
ruled out that users - due to the phenomenon of 'confirmation bias' - would continue to believe false news because it is more in line with their opinions and with their prejudices. Algorithms could also replicate and amplify user bias, especially in a highly polarized political context (Nyhan and Reifler 2010, Pennycook and Rand 2017). On the other hand, even if it were possible to develop algorithms capable of completely eliminating fake news harmful to democracy, useful news would also disappear, which, however, should still be available to users (Giglietto et al. 2016, Nyhan 2017).

At the same time, legislation would need to provide for debunking tools, aimed at doubting or denying, on the basis of scientific methodologies, false claims. But even these tools may not produce the desired effects. Once the news has been widespread, it is unlikely that a denial will reach all users who have read and shared it, regarding it as true. Moreover, the possible denial of false news, spread on the Net, risks it not being taken into consideration. In this regard, the research by Zollo et al. (2017) has shown that debunking is not effective because debunking posts tend to stimulate negative comments of users and fail, however, to change their initial opinions; indeed, users are inclined to believe that widespread truth is the result of a conspiracy to stem the fake truth they believe in and, therefore, continue to spread fake news (Zollo et al. 2017).

Finally, regulation that enhances Media Literacy would be appropriate, in order to develop knowledge and a critical spirit of citizens that allow them to evaluate a news item with greater objectivity. Even the tool of Media Literacy, however, may not produce the expected effects. In this regard, we agree with De Keersmaecjer and Roets (2017) who have highlighted that Media Literacy, operating through rational processes, may not work because there is an emotional and irrational aspect that, as we have seen, leads users to believe in fake news (De Keersmaecjer and Roets 2017). Moreover, Royster (2017) and Jolls and Johnsen (2018) have shown in their studies that the literacy programs, so far adopted, have not been effective (Royster 2017, Jolls and Johnsen 2018).

In conclusion, it can be argued that all the measures examined so far, or introduced in some countries, present problems, both in relation to their implementation and their effectiveness. Furthermore, it is difficult to impose obligations on platforms that constitute commercial giants that aim at profit. However, it is believed that, faced with a 'concrete' risk for democracy, individual States or the European Union must take all possible measures to deal with the phenomenon of the impact of algorithms on democratic values and processes. A regulation should therefore be adopted which envisages a mix of measures aimed at: limiting the creation and dissemination of fake news, specifically created to manipulate political opinion and the voting of the voters; making the functioning mechanisms of the algorithms more transparent; providing for transparency obligations and tools to identify the author of the false news, through forms of accountability in the dissemination of the same and the possibility of denying them, through debunking tools, rectifying them or, sometimes, removing them, after an evaluation by a judicial authority; enhancing the Media Literacy of network users to develop in them a critical spirit towards the news. 
Of course, we are aware that even by adopting all the measures described above, at the same time, this will not solve the problem of the impact of algorithms on democracy. But it is believed that States and the European Union must take firm action to limit, at least in part, the distorting effects of this phenomenon.

\section{References}

Aalberg T, Curran J (2012) How media inform democracy: a comparative approach. New York, London: Routledge.

Allcott H, Gentzkow M (2017) Social media and fake news in the 2016 Election. Journal of Economic Perspectives 31(2): 211-236.

Baker CE (1998) Media that citizens need. University of Pennsylvania Law Review 147(2): 317-408.

Bakshy E, Messing S, Adamic LA (2015) Exposure to ideologically diverse news and opinion on facebook. Science 348(6239): 1130-1132.

Balkin JM (2018) Free Speech in the algorithmic society: big data, private governance, and new school speech regulation. University of California Davis Law Review 51(3): 1149-1209.

Baron S, Crootof R (2017) Fighting fake news-workshop report. In The Information Society Project \& the Floyd Abrams Institute for Freedom of Expression. USA: Yale University.

Barthel M, Mitchell A, Holcomb J (2016) Many Americans believe fake news is sowing confusion. In Pew Research Center. Retrieved from: https://pewrsr.ch/2YUkekO.

Bassini M, Vigevani G (2017) Primi appunti su fake news e dintorni. (First notes on fake news and surroundings). Media Laws. Rivista di diritto dei media 1(Oct): 11-22.

Bennett WL, Livingston S (2018) The disinformation order: disruptive communication and the decline of democratic institutions. European Journal of Communication 33(2): 122-139.

Berghel H (2017) Oh, what a tangled web: Russian hacking, fake news, and the 2016 US presidential election. Computer 50(9): 87-91.

Bistagnino G, Fumagalli C (2018) Fake news, post-verità e politica. (Fake news, posttruth and politics). Milano: Feltrinelli.

Boccia Artieri G, Marinelli A (2018) Introduzione: piattaforme, algoritmi, formati. Come sta evolvendo l'informazione online. (Introduction: platforms, algorithms, formats). How online information is evolving). Problemi dell'Informazione XLIII(3): 349-368.

Borello R (2017) Alcune riflessioni preliminari (e provvisorie) sui rapporti tra i motori di ricerca ed il pluralismo informative. (Some preliminary (and provisional) reflections on the relationships between search engines and information pluralism). Media Laws. Rivista di diritto dei media $1(\mathrm{Oct})$ : 68-78.

Butler A (2018) Protecting the democratic role of the press: a legal solution to fake news. Washington University Law Review 96(2): 419.

Caravita B (2018) Il consenso ai tempi dei social. (Consent in the time of social media). Federalismi.it 13(Jun). Retrieved from: https://bit.ly/3fCzWa6.

Caravita B (2019) Social network, formazione del consenso, istituzioni politiche. Quale regolamentazione possibile. (Social networks, consensus building, political institutions. What regulation possible). Federalismi.it 2(Jan): 3. Retrieved from: https://bit. ly/35Qt30I. 
Ciarlo P (2018) Democrazia, partecipazione popolare e populismo al tempo della rete. (Democracy, popular participation and populism at the time of the network). Rivista AIC 2(Jun): 1-11.

Costa P (2016) Motori di ricerca e social media: i nuovi filtri nell'ecosistema dell' informazione online e il potere oscuro degli algoritmi. (Search engines and social media: new filters in the online information ecosystem and the dark power of algorithms). In G Avanzini, G Matucci (Eds), 251-272. L'informazione e le sue regole. Libertà, pluralismo e trasparenza. Napoli: Editoriale Scientifica.

Cuniberti M (2017) Il contrasto alla disinformazione in rete tra logiche del mercato e (vecchie e nuove) velleità di controllo. (The contrast to the disinformation on the net between market logic and (old and new) control ambitions). Media Laws. Rivista di diritto dei media $1(\mathrm{Oct}):$ : 26-40.

D'Atena A (2018) Tensioni e sfide della democrazia. (Tensions and challenges of democracy). Rivista AIC 3 (Feb): 15.

De Keersmaecjer J, Roets A (2017) 'Fake news': incorrect, but hard to correct. The role of cognitive ability on the impact of false information on social impression. Intelligence 65(Nov): 107-110.

Del Vicario M, Quattrociocchi W, Scala A, Zollo F (2019) Polarization and fake news: early warning of potential misinformation targets. ACM Transactions on the Web 13(2).

Della Porta D, Fernández J, Kouki H, Mosca L (2017) Movement parties against austerity. Cambridge: Polity Press.

Donald B (2016) Stanford Researchers find students have trouble judging the credibility of information online. In Stanford News CTR. Retrieved from: https://stanford.io/2YV W0Xp.

Donati F (2017) Fake news e libertà di informazione. (Fake news and freedom of information). I diritti dell'uomo 1(Jun): 51.

Faris R, Roberts H, Etling B, Bourassa N, Zuckerman E, Benkler Y (2017) Partisanship, propaganda, and disinformation: online media and the 2016 U.S. presidential election. Harvard, USA: Berkman Klein Center. Retrieved from: https://cyber.har vard.edu/publications/2017/08/mediacloud.

Frankovic K (2016) Belief in conspiracies largely depends on political identity. In Richard Dawkins Foundation for Reason \& Science. Retrieved from: https://bit.ly/2yL2H3Y.

Frosini TE (2017) No news is fake news. in Diritto Pubblico Comparato Ed Europeo 5(4): 5-6.

Gallone F (2019) Fake news, un fenomeno sempre più pericoloso. (Fake news, an increasingly dangerous phenomenon). In G Cricenti, F Gallone (Eds), Non è Vero ma ci Credo. Come le Fake News Inquinano la Democrazia. Roma: Armando Editore: 57-133.

Gaughan AJ (2017) Illiberal democracy: the toxic mix of fake news, hyperpolarization, and partisan election administration. Duke Journal of Constitutional Law \& Public Policy 12(May): 57-139.

Giglietto F, Iannelli L, Valeriani A, Rossi L (2016) Fakes, news and the election: a new taxonomy for the study of misleading information within the hybrid media system. In Current Sociology. AssoComPol Convention 2016 (Urbino, 15-17 December 2016).

Gili G, Maddalena G (2017) Chi ha paura della post-verità? Effetti collaterali di una parabola culturale. (Who is afraid of post-truth? Side effects of a cultural parable). Genova-Milano: Marietti.

Goldberg D (2018) Responding to 'fake news': is there an alternative to law and regulation? Southwestern Law Review 47: 417-447. 
Grassegger H, Krogerus M (2017) La politica ai tempi di facebook. (Politics in the days of Facebook). Internazionale 40.

Groshek J, Koc-Michalska K (2017) Helping populism win? Social media use, filter bubbles, and support for populist presidential candidates in the 2016 US election campaign. Information Communication and Society 20(9): 1389-1407.

Gurumurthy A, Bharthur D (2018) Democracy and the algorithmic turn. 27 SURInternational Journal on Human Rights 39(Jul).

Hodas NO, Lerman K (2012) How limited visibility and divided attention constrain social contagion. In ASE/IEEE International Conference on Social Computing. Retrieved from: https://arxiv.org/abs/1205.2736.

Huighe FB (2016) Désinformation: les armes du faux. (Disinformation: the weapons of the false). Paris: Armand Colin.

Iacoboni J (2016) The affair between the five star movement and Putin's emissaries. In $L a$ Stampa. Retrieved from: https://bit.ly/2AlkLCl.

Jolls T, Johnsen M (2018) Media Literacy: a foundational skill for democracy in the $21^{\text {st }}$ century. Hastings Law Journal 69(4): 1379-1408.

Keyes R (2004) The post-truth era: dishonesty and deception in contemporary life. London: St. Martin's Press.

Klein D, Wueller JR (2017) Fake news: a legal perspective' in Journal of Internet Law 20(10): 5.

Levi L (2018) Real 'Fake News' and Fake 'Fake News. First Amend. Law Review 16(Jan): 233.

Lorusso AM (2018) Postverità. (Post Truth). Bari-Roma: Editori Laterza.

Manetti M (2018) Costituzione, partecipazione democratica, populismo. (Constitution, democratic participation, populism). Rivista AIC 3(Nov): 389.

Mazzoleni G (2012) La comunicazione politica. (Political communication). Bologna: il Mulino.

McNair B (2017) Fake news: falsehood, fabrication and fantasy in journalism. London: Routledge.

Mezza M (2018) Algoritmi di libertà. La potenza del calcolo tra dominio e conflitto. (Freedom algorithms. The power of calculation between domination and conflict). Roma: Donzelli Editore.

Morgan S (2018) Fake news, disinformation, manipulation and online tactics to undermine democracy. Journal of Cyber Policy 3(1): 39-43.

Morozov E (2011) The net delusion. The dark side of internet freedom. New York: PublicAffair.

Nematzadeh A, Ciampaglia GL, Menczer F, Flammini A (2017) How algorithmic popularity bias hinders or promotes quality. Scientific Reports 8(1).

Nyhan B (2017) Why the fact-checking at facebook needs to be checked. In New York Times. Retrieved from: https://www.nytimes.com/2017/10/23/upshot/why-the-factchecking-at-facebook-needs-to-be-checked.html.

Nyhan B, Reifler J (2010) When corrections fail: the persistence of political misperceptions. Political Behavior 32(2): 303-330.

Nyhan B, Reifler J (2019) The roles of information deficits and identity threat in the prevalence of misperceptions. Journal of Elections, Public Opinion and Parties 29(2): 222-244.

Panarari M (2017) Opinione pubblica, 'fake news' e inquinamento del discorso pubblico in epoca postmoderna. (Freedom algorithms. The power of calculation between domination and conflict). I diritti dell'uomo 1: 79-84. 
Papa A (2018) 'Democrazia della comunicazione' e formazione dell'opinione pubblica. In P Bilancia (Ed), 301-332. Crisi della Rappresentanza Politica nella Democrazia Contemporanea. Torino: Giappichelli.

Pariser E (2011) The filter bubble. What the internet is hiding from you. Londra: Penguin Books.

Pasquale F (2015) The Black Box Society. The secret algorithmsn that control money and information. Cambridge, Massachusetts, London, England: Harvard University Press.

Pennycook G, Rand D (2017) Assessing the effect of 'disputed' warnings and source salience on perceptions of fake news accuracy. SSRN Electronic Journal.

Persily N (2017) The 2016 U.S. election: can democracy survive the Internet? Journal of Democracy 28(2): 63-76.

Perucchietti E (2018) Fake news. Dalla manipolazione dell'opinione pubblica alla postverità. Come il potere controlla i media e fabbrica l'informazione per ottenere consenso. (Fake news. From manipulation of public opinion to post-truth. How power controls the media and manufactures information to obtain consent). Bologna: Arianna Editrice.

Pinelli C (2017) 'Postverità', verità e libertà di manifestazione del pensiero. (Post truth, truth and freedom of manifestation of thought). Media Laws. Rivista di diritto dei media 1(Oct): 41-47.

Pitruzzella G (2017) Libertà di informazione nell'era di Internet. (Freedom of information in the Internet age). In G Pitruzzella, O Pollicino, S Quintarelli (Eds), 56-98. Parole e Potere. Libertà d'Espressione, Hate Speech e Fake News. Milano: Egea.

Pitruzzella G, Pollicino O, Quintarelli S (2017) Parole e potere. Libertà d'espressione, hate speech e fake news. (Words and power. Freedom of expression, hate speech and fake news. Milano: Egea.

Pizzetti F (2017) Fake news e allarme sociale: responsabilità, non censura. (Fake news and social alarm: responsibility, not censorship). Media Laws. Rivista di diritto dei media 1: 48-59.

Quattrociocchi W, Vicini A (2016) Misinformation. Guida alla società dell'informazione e della credulità. (Misinformation. Guide to the information society and credulity). Milano: Franco Angeli.

Quattrociocchi W, Vicini A (2018) Liberi di crederci. Informazione, internet e post-verità. (Free to believe it. Information, internet and post-truth). Torino: Codice Edizioni.

Ratkiewicz J, Conover M, Meiss M, Gonçalves B, Flammini A, Menczer F (2011) Detecting and tracking political abuse in social media. In Proceedings of the $5^{\text {th }}$ International Conference on Weblogs and Social Media, Barcelona, July 17-21, 2011.

Reaney P (2013) Teens more resilient, tech savy than older millennials. In Study, Reuters Retrieved from: https://reut.rs/3bqUAql.

Reinemann C, Aalberg T, Esser F, Strömbäck J, de Vreese CH (2017) Populist political communication: toward a model of its causes, forms and effects. In T Aalberg, F Esser, C Reinemann, FJ GStrömbäck, CH de Vreese (Eds), 12-28. Populist Political Communication in Europe. New York: Routledge.

Riva G (2018) Fake news. Bologna: il Mulino.

Royster LK (2017) Fake news: potential solutions to the online epidemic. North Carolina Law Review 96(1): 270-295.

Rožukalne A (2015) Internet news about Ukraine and the 'audience agenda': topics, sources and the audience aggressiveness. Journalism Research 8(1): 17.

Russonello G (2016) Voters fear their ballot won't count, poll shows. In New York Times. Retrieved from: https://www.nytimes.com/2016/10/26/us/politics/voter-fraud-poll. html. 
Salganik MJ, Dodds PS, Watts DJ (2006) Experimental study of inequality and unpredictability in an artificial cultural market. Science 311(5762): 854-856.

Shao C, Ciampaglia GL, Varol O, Flammini A, Menczer F (2018) The spread of fake news by social bots. Nature Communications 9(4787): 3 .

Silverman C (2016) This analysis shows how viral fake election news stories outperformed real news on facebook. In BuzzFeed News. Retrieved from: https://bit.ly/35PpasF.

Sinclair B, Wars P (2006) Polarization and the politics of national policy making. Norman, Oklahoma: University of Oklahoma Press.

Smith-Roberts A (2018) Facebook, fake news, and the first amendment. Denver Law Review 95(118): 119.

Spohr D (2017) Fake news and ideological polarization. Filter bubbles and selective exposure on social media. Business Information Review 24(3): 150-160.

Syed N (2017) Real talk about fake news: towards a better theory for platform governance. The Yale Law Journal Forum (Oct): 337-357.

Tucker A, Theocharis Y, Roberts ME, Barbera P (2017) From liberation to turmoil: social media and democracy. Journal of Democracy 28(4): 46-59.

Visco Comandini V (2018) Le fake news sui social network: un'analisi economica. (Fake news on social networks: an economic analysis). Media Laws. Rivista di diritto dei media 2: 183-212.

West DM (2017) How to combat fake news and disinformation. In Brookings Retrieved from: https://www.brookings.edu/research/how-to-combat-fake-news-and-disinfor mation.

Ziccardi G (2019) Tecnologie per il potere. Come usare i social network in politica. (Technologies for power. How to use social networks in politics). Milano: Cortina Editore.

Zollo F, Bessi A, Del Vicario M, Scala A, Caldarelli G, Shekhtman L et al. (2017) Debunking in a world of tribes. In PLoS One 12(7): e0181821.

Zuiderveen Borgesius FJ, Trilling D, Möller J, Bodó B, de Vreese CH, Helberger N (2016) Should we worry about filter bubbles? Internet Policy Review 5(1). 